\title{
Influence of Aggregate Grain Size on the Formulation of Sand Concrete in the Construction Industry in Congo
}

\section{Charlène Bassolokidi Nkengue ${ }^{1}$, Narcisse Malanda ${ }^{*}$, Gilbert Ganga1, Paul Louzolo-Kimbembe1, Guy Richard Mouengue ${ }^{2}$}

${ }^{1}$ National Higher Polytechnic School, Marien Ngouabi University, Brazzaville, Congo

${ }^{2}$ Office of Control of Buildings and Public Works, Brazzaville, Congo

Email: ^nar6malanda@gmail.com, *narcisse.malanda@umng.cg

How to cite this paper: Nkengue, C.B., Malanda, N., Ganga, G., Louzolo-Kimbembe, P. and Mouengue, G.R. (2019) Influence of Aggregate Grain Size on the Formulation of Sand Concrete in the Construction Industry in Congo. Geomaterials, 9, 81-96. https://doi.org/10.4236/gm.2019.94007

Received: September 26, 2019

Accepted: October 28, 2019

Published: October 31, 2019

Copyright $\odot 2019$ by author(s) and Scientific Research Publishing Inc. This work is licensed under the Creative Commons Attribution-NonCommercial International License (CC BY-NC 4.0). http://creativecommons.org/licenses/by-nc/4.0/

\section{Open Access}

\begin{abstract}
The main objective of this study is to contribute to the optimization of the formulation of sand concretes and its valorisation according to natural sands from different quarries or extraction sites. Physical characteristics of natural sands have been determined and improved by the addition of crushing sand, taking into account the too fine elements of the sand. Four types of sand were used (Congo River, Djiri, Mfilou, crushed sand). The concrete formulations proposed from improved sands (30\% crushed sand and $70 \%$ natural sand) reveal an increase in mechanical strength. Thus, it appeared that this improvement of the natural fine sands by the crushing sand has brought a clear increase in the maneuverability of the concretes and the physico-mechanical characteristics of nearly $50 \%$, although this crushing sand has a sand equivalent value of less than $70 \%$. These results augur well for the durability of structures in the construction industry in Congo.
\end{abstract}

\section{Keywords}

Sand, Formulation, Recovery, Materials, Sand Concrete, Physico-Mechanical Characteristics, Construction

\section{Introduction}

Over the past 40 years, the use of sand concrete has become more and more common. Indeed, this material made from sand, cement, water and other admixtures tries to replace traditional common concrete in certain construction fields (bricks, cinder blocks, roughcasts, paving stones, low-stress structures, 
etc.), not only because of the rarity of gravel in certain areas, but also because of the technical performance that this material offers, particularly its low cracking properties and good workability [1]. However, its durability and resistance are closely linked to the physicochemical and mechanical properties of its components [2]. For more than a dozen years, Congo has been living in an era of high socio-economic development ambitions and basic infrastructure (roads, hospitals, schools, etc.), despite the recession it has experienced in recent years. However, the construction industry, in terms of regulation and standardization, is still in its infancy. Thus, we often see self-construction in the construction of single-family homes or even other public infrastructure. Several structures made or prefabricated products with sand concrete are used in the construction of buildings without precaution in the formulation of the said concretes. And, according to preconceived ideas, the field of building construction remains dominated by a sector qualified as informal or semi-informal. Indeed, in some developing countries, this sector contributes to nearly $90 \%$ of housing production [3], and at the same time the quality assurance of the works or structures carried out is not always guaranteed, thus causing early damage [4]. However, according to Turcy et al. (2003), concrete formulation is understood as the process of selecting constituent materials in their appropriate proportions in order to obtain the required properties (consistency, strength, durability, etc.), but in most cases, this is still done empirically [5]. However, the main concern of this study remains in the formulation of sand concretes in order to obtain good workability and good characteristics [1], since the quality of a structure necessarily depends on the physicochemical and mechanical performance of the construction materials used. Sand concrete is highly appreciated for its compressive strength. However, it is necessary to specifically consider each of its components, among which is sand. Sand has various characteristics that influence the good behaviour of concrete [6]. And, in several countries, sand concrete is becoming increasingly important in the construction industry thanks to its qualities, particularly its workability, its lack of segregation and its aesthetic qualities [7]. It is currently one of the most widely used building materials in the world (for nearly two thirds of all homes in the world). But, the perpetual quest for suitable aggregates, mainly sand, leads to improvements sometimes by adding another type of sand that is more suitable. Moreover, crushing sands are very often the only alternative. However, they must meet the criteria of cleanliness quality and be available, otherwise, this ipso facto leads to an increase in the dosage of cement (not economical), which releases much more heat of hydration, and causes damage to massive structures. In addition, the very fine grains of sand can lower the activity of cement, which significantly reduces the mechanical strength of concrete. In addition, due to the large specific surface area of the cement, capillary absorption increases, reducing the impermeability of hardened concrete and increasing the shrinkage phenomenon. As a simple approximation, this sand concrete can be represented as a three-phase system; a phase comprising colloidal particles (mainly cement), the granular phase composed of non-colloidal 
particles (sand) and the liquid phase which corresponds to the mixing water loaded with ions from the dissolution of the cement and dissolved polymers. Thus, the liquid phase can be assimilated to the interstitial fluid of an evolving porous medium saturated with water, composed of the two solid phases (colloidal and non-colloidal). This system, referred to as cemented granular material or cementitious matrix, is subject to external water and thermal stresses. In addition, it is applied on a support that will also be considered as a porous medium. Thus, the mortar loses its mixing water due to evaporation and suction of the substrate [8]. If the water loss is too high, cracking and loss of adhesion are the two main pathologies observed [9]. In other words, it is necessary to control the technical performance of the aggregates (sands) and even the mechanical characteristics of the concretes.

In our work, we are first interested in the characterization of different types of sand taken from different quarries and improved with crushing sand. Then, concrete is manufactured whose compressive and tensile strength is evaluated or assessed to ensure quality assurance of the structures. The main aim of this study is to achieve good mechanical strength of sand concrete and correct handling by using CEM II cement.

\section{Materials and Methods}

\subsection{Geographical Coordinates and Materials Used}

All aggregates (sands) were collected from the following quarries, including extraction from the Congo River.

Table 1 lists the geographical coordinates of the four (4) quarries from which we sampled. These sands are all O/D aggregates that comply with NF P18-101 and NF P18-301 standards. They can be of various origins, natural sand (alluvial, river or dune) with its equivalent of sand as a specific criterion [10].

\subsection{Geotechnical Characterization of Sands}

For sand identification and characterization, the following tests were performed:

- Granulometric analysis [NF P933-1 Standards];

- The bulk density [Standard EN 1097-6];

- The measurement of specific weight [Standard NF EN 94-054];

- The sand equivalent test [Standard NF EN 933-8; XP18-540];

- Tests on cement [Standard EN 197-1];

- The methylene blue test [NFP 18-592].

The binder used throughout this study is CEM II 42.5 cement.

\subsection{The Formulation of Sand Concrete}

This formulation is carried out in accordance with EN-196-1. It requires the use of small diameter aggregates $(\leq 5 \mathrm{~mm})$. However, the addition of coarse aggregates is possible but in a G/S ratio (Gravel/Sand less than 1) [1].

The different formulations were proposed according to the natural sand material including the improvements according to Table 2. 
Table 1. Geographical coordinates of quarries and sand sampling sites.

\begin{tabular}{ccc}
\hline Quarries & Latitude & Longitude \\
\hline Kombé (crushed sand) & $04^{\circ} 21^{\prime} 04.6^{\prime \prime}$ & $015^{\circ} 10^{\prime} 18.9^{\prime \prime}$ \\
Fleuve (river sand) & $04^{\circ} 21^{\prime} 41.1^{\prime \prime}$ & $015^{\circ} 10^{\prime} 16.5^{\prime \prime}$ \\
Djiri (white sand) & $04^{\circ} 07^{\prime} 15.8^{\prime \prime}$ & $015^{\circ} 17^{\prime} 38.9^{\prime \prime}$ \\
Mfilou (white sand) & $04^{\circ} 13^{\prime} 00.5^{\prime \prime}$ & $015^{\circ} 12^{\prime} 08.5^{\prime \prime}$ \\
\hline
\end{tabular}

Table 2. Various proposals for improved sand.

\begin{tabular}{cccc}
\hline Sample & Water quantity (g) & $\begin{array}{c}\text { Quantity of } \\
\text { cements (g) }\end{array}$ & $\begin{array}{c}\text { Quantity of } \\
\text { sand (g) }\end{array}$ \\
\hline $\begin{array}{c}\text { Improved Mfilou sand } \\
(30 \% \text { crushed sand + 70\% Mfilou) } \\
\text { Improved Djiri sand }\end{array}$ & 225 & 405 SC + 945 Mfilou & 450 \\
$\begin{array}{c}\text { (30\% crushed sand + 70\% Djirisand) } \\
\text { Improved River sand }\end{array}$ & 225 & 405 SC + 945 Djiri & 450 \\
$(30 \%$ crushed sand + 70\% River $)$ & 225 & 405 SC + 945 River & 450 \\
\hline
\end{tabular}

Note: 405 SC + 945 Mfilou represents 405 grams of crushed sand and 945 grams of sand from Mfilou, Djiri or the Congo River.

\section{Results and Discussions}

\subsection{Interpretation of the Results of Physicomechanical Tests}

\section{$\checkmark$ Sand identification tests}

Table 3 and Table 4 represent the granularity of the local sands used and the spindle of the normalized sand. These results show that not all the sands from the Brazzaville quarries used enter the normalized sands spindle. However, the crushing sand enters the spindle, but it does not contain all the possible elements. In addition, the sands of the river, Mfilou and the Djiri quarry are very far from the spindle and including many others (Annex 1). There is also the similarity between Djiri sand and Mfilou sand in that they do not have particles of $1 \mathrm{~mm}$ or more in size and are practically confused, suggesting that river sand, Djiri sand and Mfilou sand are carried by wind or rainwater. Thus, they have fine sand characteristics. Some corrections have been made to the Mfilou, Djiri, and river sands to allow them to enter the normalized sands spindle (Annex 2).

All other parameters relevant for the characterization of these types of sand are presented in Table 5 and Appendix 3. It can be seen that the fineness modules for the Djiri and Mfilou quarries and the Congo River quarries are less than 2.22 , except for the one resulting from crushing. In view of these different percentages of fines and their granularity, we can deduce that these same sands are very fine.

\section{$\checkmark$ Methylene blue value}

The methylene blue values are all well below 1, which confirms that these sands are not contaminated with clay. There is practically no clay activity in these sands (Table 6). 
Table 3. Granulometric analysis of quarry sands.

\begin{tabular}{ccccccc}
\hline $\begin{array}{c}\text { Sieve } \\
(\mathrm{mm})\end{array}$ & $\begin{array}{c}\text { Strainer } \\
\phi \mathrm{mm}\end{array}$ & $\begin{array}{c}\text { Module } \\
\text { AFNOR }\end{array}$ & Djiri sand & Mfilou sand & $\begin{array}{c}\text { Congo River } \\
\text { sand }\end{array}$ & $\begin{array}{c}\text { Crushed } \\
\text { Sand 0/4 }\end{array}$ \\
\hline 5 & 6.3 & 38 & - & - & - & 100 \\
2.5 & 3.15 & 35 & - & - & - & 71 \\
1.25 & 1.6 & 32 & 100 & & & 53 \\
0.63 & 0.8 & 29 & 99 & 100 & 100 & 46 \\
0.315 & 0.40 & 26 & 79 & 78 & 95 & 28 \\
0.1 & 0.200 & 23 & 36 & 35 & 14 & 15 \\
0.08 & 0.1 & 20 & 9 & 7 & 3 & 9 \\
\hline
\end{tabular}

Table 4. Improved sand particle size analysis.

\begin{tabular}{cccccc}
\hline $\begin{array}{c}\text { Sieve } \\
(\mathrm{mm})\end{array}$ & $\begin{array}{c}\text { Strainer } \\
\phi \mathrm{mm}\end{array}$ & $\begin{array}{c}\text { Module } \\
\text { AFNOR }\end{array}$ & $\begin{array}{c}\text { Improved Djiri } \\
\text { sand }\end{array}$ & $\begin{array}{c}\text { Improved Mfilou } \\
\text { sand }\end{array}$ & $\begin{array}{c}\text { Improved Congo } \\
\text { River sand }\end{array}$ \\
\hline 5 & 6.3 & 38 & 100 & 100 & 100 \\
2.5 & 3.15 & 35 & 91 & 99 & 87 \\
1.25 & 1.6 & 32 & 80 & 79 & 78 \\
0.63 & 0.8 & 29 & 70 & 70 & 69 \\
0.315 & 0.40 & 26 & 48 & 53 & 86 \\
0.1 & 0.200 & 23 & 21 & 24 & 8 \\
0.08 & 0.1 & 20 & 4 & 4 & 1 \\
\hline
\end{tabular}

Table 5. The characteristic parameters of granulometric analysis.

\begin{tabular}{cccc}
\hline Aggregates & Glide module $2.2<\mathrm{Mf}<2.8$ & \% of fine to the $0.08 \mathrm{~mm}$ sieve & Granularity \\
\hline Djiri & 0.85 & 9 & $0 / 0.63$ \\
Mfilou & 0.87 & 7 & $0 / 0.63$ \\
Congo River & 0.70 & 4 & $0 / 0.63$ \\
Crushed & 2.89 & 9 & $0 / 4$ \\
\hline
\end{tabular}

Table 6. Methylene blue values.

\begin{tabular}{cc}
\hline Nature of the sample & Methylene blue value VB $<1$ \\
\hline Red sand of the Congo River & 0.1 \\
White sand from Djiri's quarry & 0.1 \\
White sand from Mfilou quarry & 0.1 \\
Crushed sand of Kombé & 0.14 \\
\hline
\end{tabular}

\section{The bulk density}

The samples were collected manually from the various quarries. During this test, we obtained the results shown in Table 7 and Appendix 4. 
Table 7. Results of the apparent densities of the different sands.

\begin{tabular}{cc}
\hline Nature of the sample & Apparent density $\left(\mathrm{t} / \mathrm{m}^{3}\right)$ \\
\hline Mixture of sand (70\% Djiri sand and 30\% crushed sand 0/4) & 1.60 \\
Mixture of sand (70\% Mfilou sand and 30\% crushed sand 0/4) & 1.58 \\
White sand from Djiri's quarry & 1.56 \\
Mfilou quarry white sand & 1.57 \\
Mixture of sand (70\% river sand and 30\% crushed sand 0/4) & 1.51 \\
Congo River Sand & 1.40 \\
Crushed sand 0/5 & 1.39 \\
\hline
\end{tabular}

The values of the different apparent densities obtained vary between 1.40 and 1.60 , which shows that the materials used meet the requirements of cleanliness and shape. However, only crushed sand $0 / 4$ has a specific weight of 1.39 .

\section{$\checkmark$ Specific weight measurement:}

The results obtained during this test of the different samples are shown in $\mathrm{Ta}$ ble 8 and Annex 5. The values obtained from the different specific weights of these materials comply with the standard (values between 2.35 and 2.65). Therefore, these materials can be used for a concrete formulation.

\section{$\checkmark$ Sand equivalent test}

The sands used in this test are: Congo River sand; Mfilou quarry sand, Djiri white quarry sand and $0 / 4$ crushed sand. The results obtained are shown in Table 9. The sand equivalent shows that the sands of Djiri, Mfilou and Le Fleuve are very clean, and can be used in concrete. On the other hand, crushing sand has a low equivalent $(E S=65)$, less than 70 , so it has more impurities and is not suitable for concrete.

\section{$\checkmark$ Physico-mechanical tests on the cement used (CEM II 42.5)}

The results obtained during these tests are summarized in Table 10 and Table 11. These binders can, therefore, be used for the formulation of concretes because they meet the requirements of the standard. The tests are carried out according to the standards (EN 196-1) and (EN 196-3) and the results of the physico-mechanical tests obtained comply with the specifications of the standard (EN 197-1).

\section{- Evolution of compressive strength (CEM II 42.5 cement)}

The results of compressive strength tests with CEM II 42.5 cement are shown in Figure 1, which shows the variation in compressive strength for the different types of mortars as a function of the immersion time in water. It shows that improved sands have the highest compressive strength, improved Djiri sand has the highest strength (29.23 MPa) followed by improved Mfilou (28.1 MPa) and then improved river sand (27.64 MPa).

The natural sands of Djiri, Mfilou and du Fleuve have low compressive strength ( $\leq 15 \mathrm{MPa})$. Compressive strength with crushed sand is higher (26.79 $\mathrm{MPa}$ ), than that of other sands: Djiri, Mfilou, and River, and have values of $13.65 ; 13.32 ; 12.26$ Mpa respectively. 
Table 8. Results of the specific weights of the different sands.

\begin{tabular}{lc}
\hline \multicolumn{1}{c}{ Nature of the sample } & Specific weights $\left(\mathrm{g} / \mathrm{cm}^{3}\right)$ \\
\hline Mixture of sand (70\% river sand and 30\% crushed sand 0/4) & 2.60 \\
Reddish sand of the Congo River & 2.59 \\
Mixture of sand (70\% Djiri sand and 30\% crushed sand 0/4) & 2.59 \\
Djiri quarry white sand & 2.58 \\
Mixture of sand (70\% Mfilou sand and 30\% crushed sand 0/4) & 2.58 \\
White sand from Mfilou quarry & 2.54 \\
Crushed sand 0/5 & 2.50 \\
\hline
\end{tabular}

Table 9. Results of sand equivalents of different types of sand.

\begin{tabular}{cc}
\hline Nature of the sample & Value of sand equivalent (\%) \\
\hline Red sand of the Congo River & 88 \\
White sand from Djiri's quarry & 84 \\
White sand from Mfilou quarry & 83 \\
Crushed sand of Kombé & 65 \\
\hline
\end{tabular}

Table 10. Physical properties of cement CEM II 42.5.

\begin{tabular}{ccc}
\hline Physical properties & Values obtained & Standards EN 197-1 \\
\hline Grit size $(\%) ; 80$ sieve $(\mu \mathrm{m})$ & 3.5 & $\leq 5$ \\
Bulk density $(\mathrm{g} / \mathrm{cm})$ & 0.95 & $0.95-1.10$ \\
Start of setting $(\mathrm{mn})$ & $90(\mathrm{~mm})$ & $\geq 60$ \\
End of shooting $(\mathrm{mn})$ & $123(\mathrm{~mm})$ & $\leq 720$ \\
Setting time & & - \\
Class & 42.5 & - \\
Consistency $(\%)$ & 25 & $\geq 42.5$ \\
\hline
\end{tabular}

Table 11. Mechanical characteristics of CEM II cement 42.5 .

\begin{tabular}{ccc}
\hline Mechanical properties & Values obtained & Standard EN 197-1 \\
\hline Rc $2 \mathrm{j}$ & 15.52 & $\geq 10 \mathrm{MPa}$ \\
Rc $7 \mathrm{j}$ & 29.27 & - \\
Rc $28 \mathrm{j}$ & 42.08 & $42.5-62.5 \mathrm{MPa}$ \\
Rt $2 \mathrm{j}$ & 3.71 & $\geq 4.0 \mathrm{MPa}$ \\
Rt $7 \mathrm{j}$ & 5.81 & - \\
Rt $28 \mathrm{j}$ & 6.4 & $\geq 6.5 \mathrm{MPa}$ \\
\hline
\end{tabular}

\section{- Evolution of tensile strength by bending (CEM II 42.5 cement)}

The results of bending tensile strength tests with CEM II cement are shown in Figure 2 . 


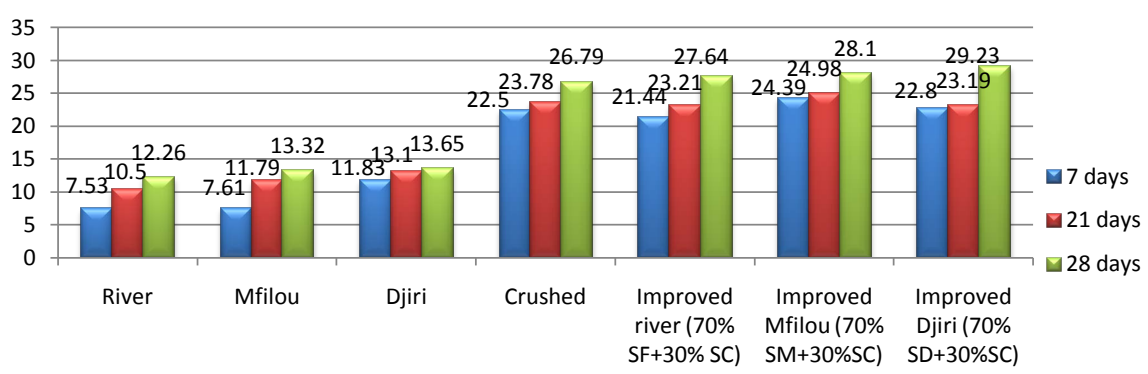

Figure 1. Normal compressive strength.

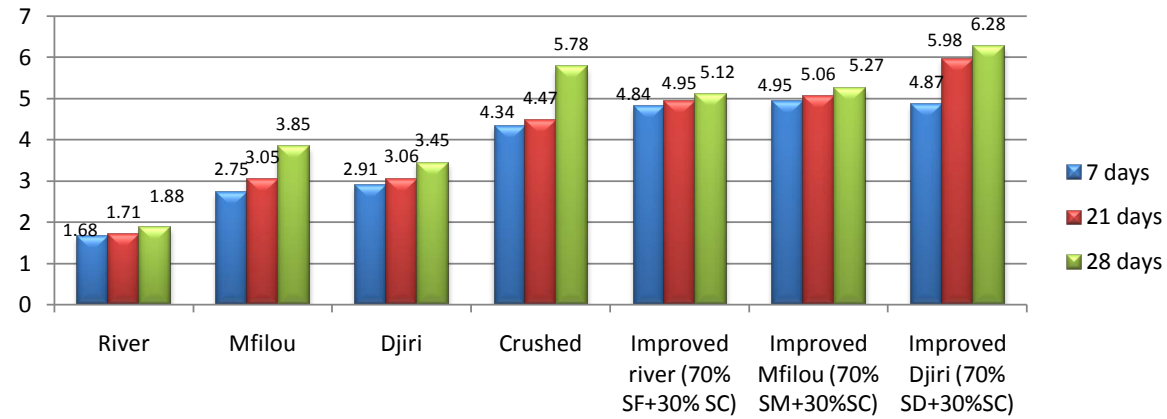

Figure 2. Tensile strength by bending of cement CEM II 42.5 .

From Figure 2, it can be seen that bending tensile strength increases with age for all types of concrete. This is due to the development of cement hydration as a function of time. The best resistance observed corresponds to the mortar of the improved sand, the improved Djiri sand seems to have the highest bending strength $(6.28 \mathrm{MPa})$, followed by crushed sand (5.78 Mpa). It should also be noted that the improved sands of the river and Mfilou show a similar evolution of tensile strength at 28 days in the order of (5.12 MPa) and (5.27 MPa) respectively. The natural sands (Mfilou and Djiri and du Fleuve) have low tensile strength values.

Based on the results obtained, it appears that the physical properties of sand influence the mechanical characteristics of sand concretes. Although the natural sands (Djiri, Mfilou and Congo River sands) are improved with 0/4 crushed sand, they are still rich in fine elements. We can, therefore, conclude that the improvement of natural fine sands with crushed sand is an important mixture in the formulation of these concretes. These observations are in line with those already available in the literature. In short, the compressive strength and tensile strength increases with time regardless of the type of cement or sand.

\subsection{Interpretation of the Results of Descriptive Statistics}

\section{$\checkmark$ Compressive strength (cement CEM II 42.5)}

The reinforcement of natural sand by crushed sand has improved the normal compressive strength of sand concrete. On the other hand, mechanical strength is little affected by age. Indeed, for natural sand concretes, by observing the confidence intervals of the mean values of normal compressive strength, it appears 
from our results that their mean evolutions are statistically the same between 7 days, 21 days and 28 days (Table 12).

For improved sand concretes, it is noted that between 7 days and 21 days, the average compressive strength did not statistically change (see their confidence intervals). However, between 21 and 28 days, there is a significant difference between the two averages (Table 12).

\section{Data on Tensile Deflections}

\section{$\checkmark$ Tensile strength by bending cement CEM II}

For the bending tensile strength illustrated in Table 13, it can be seen that the addition of crushed sand in natural sands only improved the strength of 7-day and 21-day curing concrete because according to these results, the best normal compressive strengths are given by the improved sands (for 7-day and 21-day curing concretes). For concretes with 28 days of curing, we performed a statistical test. The latter revealed that there is no significant difference between the two average resistances (3.74 MPa and 5.56 MPa).

The analyses in the table below also revealed that regardless of the type of sand (natural or improved), the bending strength did not change significantly on average.

\section{Discussion}

Several studies have been carried out in the context of the formulation and upgrading of sand concretes. These works have been the subject of several publications, including those found in the literature [1] [4] [5] [8] [11]-[22]. All this research work has first highlighted the importance and influence of the physicochemical properties of sands, which have a dominant effect on the quality of the sand concretes to be produced. Then, these studies reveal that fine sand taken as an aggregate is not suitable. Also, according to Hasdemir et al. (2016), the strength of concrete is related to the composition of the sands used in formulations. The presence of clay, for example, which reflects the impurity of natural sand, reduces this resistance [20]. Similarly, sand is a material of choice for the preparation of mortar and concrete. It plays a major role in the composition of the mixture. These aspects were also mentioned by these authors and the results

Table 12. Descriptive statistics of normal compressive strengths by hardening age and sand type with CIMAF cement.

\begin{tabular}{lllll}
\hline \multirow{2}{*}{ Aggregates } & & \multicolumn{2}{l}{ Compressive strength } \\
\cline { 3 - 5 } & & 7 days & 21 days & 28 days \\
\hline \multirow{3}{*}{ Natural sand } & Average & 12.37 & 14.79 & 16.51 \\
& IC (95\%) & {$[5.46-19.27]$} & {$[8.83-20.76]$} & {$[9.76-23.25]$} \\
& Standard deviation & 7.05 & 6.08 & 6.88 \\
& Average & 22.88 & 23.79 & 28.32 \\
\multirow{2}{*}{ Improved sand } & IC (95\%) & {$[21.21-24.55]$} & {$[22.63-24.96]$} & {$[27.4-29.25]$} \\
& Standard deviation & 1.48 & 1.03 & 0.82 \\
\hline
\end{tabular}


Table 13. Descriptive statistics of bending strength by age of hardening and type of sand (CEM II cement 42.5).

\begin{tabular}{lllll}
\hline \multirow{2}{*}{ Aggregates } & & \multicolumn{3}{l}{ Tensile strength by bending CEM II } \\
\cline { 3 - 5 } & & 7 days & 21 days & 28 days \\
\hline \multirow{2}{*}{ Natural sand } & Average & 2.92 & 3.07 & 3.74 \\
& IC (95\%) & {$[1.85-3.99]$} & {$[1.97-4.18]$} & {$[2.17-5.31]$} \\
& Standard deviation & 1.09 & 1.13 & 1.60 \\
& Average & 4.89 & 5.33 & 5.56 \\
\multirow{2}{*}{ Improved sand } & IC (95\%) & {$[4.82-4.95]$} & {$[4.69-5.97]$} & {$[4.84-6.27]$} \\
& Standard deviation & 0.06 & 0.57 & 0.63 \\
\hline
\end{tabular}

reported in the literature are also consistent with our research findings in this study. However, when natural sand does not meet the performance criteria of concrete, the approach to remedy it is to replace it.

Crushing sand is often used, which fits well into the spindle in accordance with the standard. Thus, the physical and chemical properties of crushed sand meet the requirements of fine aggregates, but the only major limitation is the decrease in manoeuvrability that can be overcome by the use of additives [21] [22]. Similarly, the effect of marble powder and green as a substitute for fine aggregates on the strength and durability of sand concrete is convincing.

Also, macroscopic studies have also confirmed the viability of using green sand and marble as fine aggregates [23]. On the other hand, studies conducted by (Opara et al. 2018) have also shown that river sand concrete has a higher density and compressive strength than quarry dust concrete for all curing ages. Indeed, after 28 days of curing, river sand concrete exceeded the target compressive strength by $36 \%$ [24].

Crushed granite has also been used as a substitute sand for sand concretes, but although compressive strength seems interesting, its production requires a higher cement to water ratio [25]. Taking into account the few weaknesses noted for natural sand in terms of physical properties, the use of crushing sand as a solution for improving these qualities is recommended. This sand can be considered as an alternative to improve quarry and river sand [24] [26]. In addition, from the point of view of the drying kinetics of sand concrete, the sorption/desorption rate is low. Surface stress gradients are low and the resulting cracking stress is low. This particular kinetics of sand concrete drying explains the non-cracking nature of the material.

\section{Conclusion}

The objective of this work was to study the influence of the grain size of the sands of the Mfilou, Djiri and Congo River quarries and crushing on the performance of sand concrete.

The method adopted consists of a physicomechanical characterization of the 
selected sands taken as aggregates by the following tests: granulometric analysis, bulk density, specific gravity, sand equivalent. These sands have been improved with crushing sand since they do not enter the normalized sand spindle, we have improved three sands (Mfilou, Djiri, and Congo River) so that they enter the spindle ( $30 \%$ of the crushed sand $+70 \%$ of natural sand). In addition, the concretes were prepared from each of these natural sands and improved to appreciate their mechanical strength. The results obtained indicate that sand concrete resists compression well and its characteristic strength was reached after 28 days. These results obtained after improvement by crushing sand are about 50\% higher than those obtained from natural fine sand.

In the results obtained, it appeared that crushed sand concrete $(0 / 4)$ has the best compressive strength and bending tensile strength due to its good granularity. Quarry sands (Mfilou and Djiri), and river sands gave very low resistances $(<15 \mathrm{MPa})$ for both cement classes (42.5 and 32.5) due to the absence of elements with sizes greater than 0.63 .

In addition, the $\mathrm{E} / \mathrm{C}$ ratio of 0.5 does not provide the best mechanical strength results for natural sands. This requires an increase in mixing water. On the other hand, the resistances with improved sands gave the best resistances with the same amount of water.

In short, the presence of a high level of fine elements increases the amount of water to be incorporated; the finer the sand, the more water it absorbs. Also, crushed sand also contains a high level of fine elements, which results in a high absorption of mixing water. The workability of sand concrete increases with the increase of the $\mathrm{E} / \mathrm{C}$ ratio regardless of the cement dosage.

\section{Acknowledgements}

This work was carried out as part of a collaboration between the National Higher Polytechnic Schooland the Office of Control of Buildings and Public Works. The authors would like to express their gratitude to the managers and agents who contributed to the development of this work.

\section{Conflicts of Interest}

The authors declare no conflicts of interest regarding the publication of this paper.

\section{References}

[1] Keinde, D., Sene, N.A., Mamadou, D. and Gueye, P.M. (2017) Study of Sand Concrete from Senegal. Revue du CAMES-Sciences Appliquées et de PIngénieur, 2, 29-36.

[2] Dupain, R., Lanchon, R. and Saint-Arron, J.C. (2004) Granulats, sols, ciment et bétons. Caractérisation des matériaux de génie civil par les essais de laboratoire, Nouvelle édition conforme aux normes européennes, BAC, BTS, DUT, Collection A. Capliez-Edition CASTEILLA. École Française du béton, 236 p.

[3] Dreux, G. and Festa, J. (1998) Nouveau guide du béton et de ses constituants, 
Huitième édition, Troisième tirage 2007, EYROLLES Ed., Paris.

[4] Poinot, T. (2013) Influence des hydroxypropylguars sur les propriétés des mortiers de ciment à l'état frais. Autre. École Nationale Supérieure des Mines de Saint-Etienne.

[5] Selma, L. (2015) Université Mohamed Khider-Biskra Faculté des Sciences et de la technologie Département: De génie civil et hydraulique: Effets desadjuvants fluidifiants sur les Caractéristiques physico-mécaniques et Rhéologiques des mortiers a base des sables des Carrières.

[6] Cimbéton (2005) Les constituants des bétons et des mortiers. chapitre 2. Paris. Septembre.

[7] Nicot Pierre, M. (2008) Interactions mortier-support: Éléments déterminants des performances et de l'adhérence d'un mortier, thèse de doctorat, université de Toulouse.

[8] Benabed, B., Azzouz, L., El-hadj, K., Eddine, A.S. and Belaidi, H.S. (2012) Propriétés physico-mécaniques et durabilité des mortiers à base du sable de dunes, université d'Amar Telidji de Laghouat, Algérie.

[9] Pettang, C., Vermande, P. and Zimmermann, M. (1995) Impact du secteur informel dans la production de l'habitat au Cameroun. $21 \mathrm{p}$.

[10] Turcy, P. and Loukili, A. (2003) Différentes approches pour la formulation des bétons autoplaçants. Revue Française de Génie Civil, 7, 425-450.

https://doi.org/10.1080/12795119.2003.9692503

http://hal.Archives-ouerts.fr/hal-01006744

[11] Benaissa, A., Morlier, P. and Tram, V. (n.d.) Le béton de sable un matériau non fissurant. Matériaux. http://www.entp.edu.dz

[12] Guendouz, M., Debielo, F. and Kadri, E.H. (2015) Formulation et caractérisation d'un béton de sable à base de déchets plastiques. 33èmes rencontres de l'AUGC, ISABTP/UPPA, Anglet, 27 au 29 Mai 2015.

[13] Guettala, A., Mezghiche, B. and Chebili, R. (1999) Strengh Comparisons between Polled sand Concrete and Dune Sand Concrete. Courrier du savoir, No. 2, 85-89.

[14] Bedenina, M., Mouldi Mouldi, K., Dheilly, R.M. and Quemendec, M. (2005) Rense of Local Sand: Effect of Limestone Filler Proportion on the Rheological and Mechanical. Cement and Concrete Research, 35, 1172-1179. https://doi.org/10.1016/j.cemconres.2004.07.006

[15] El Euch Khay, S., Neji, J. and Loulizi, A. (2010) Compacted Sand Concrete in Pavement Construction: An Economical and Environment Solution. International Concrete Abstracts Portal, 107, 195-202. https://doi.org/10.14359/51663583

[16] Béton de sable-caractéristiques et pratiques d'utilisation (1996) Projet national de recherche et de développement SABOCRETE. Presses de l'ENPC.

[17] El Euch Khay, S., Neji, J. and Loulizi, A. (2010) Shrinkage Properties of Compacted Sand Concrete Used in Pavements. Construction and Building Materials, 24, 1790-1795. https://doi.org/10.1016/j.conbuildmat.2010.02.008

[18] Jaballah Slaoui, A. and El Euch Khay, S. (2014) Valorisation du béton de sable dans le secteur du bâtiment. https://www.researchgate.net/publication/318760988-valorisation

[19] Abdeljalil, Z. and Abriak, N.E. (2009) Étude de formulation d'un béton de sable à base de sable de dragage.

[20] Hasdemir, S., Tuguil, A. and Yilmaz, M. (2016) The Effect of Natural Sand Composition on Concrete Strength. Construction and Building Materials, 112, 940-948. https://doi.org/10.1016/j.conbuildmat.2016.02.188 
[21] Sankh, A.C., Biradar, P.M., Naghathan, S. and Ishmargol, M.B. (2014) Recent Trends in Replacement of Natural Sand with Different Alternatives. IOSR Journal of Mechanical and Civil Engineering, 59-66.

[22] Hamid Mir, A. (2015) Improved Concrete Properties Using Quarry Dust as Replacement for Natural Sand. International Journal of Engineering Research and Development, 11, 46-52.

[23] Natarayan, S. and Murugesan, P. (2019) Synergistic Effect of Marble Powder and Green Sand of the Mechanical Properties of Metakaolin-Cement Concrete. Materials, 12, 476. https://doi.org/10.3390/ma12030476

[24] Opara, H.E., Eziefula, U.G. and Eziefula, B.I. (2018) Comparison of Physical and Material Properties of River Sand Concrete with Quarry Dust Concrete. Journal of Civil Engineering, 13, 127-134. https://doi.org/10.1515/sspjce-2018-0012

[25] Joel, M. (2010) Use of Crushed Granite Fine as Replacement to River Sand in Concrete Production. Leonardo Electronic Journal of Practices and Technologies, 9, 85-96.

[26] Mandra, S., Sindhi, P.R., Chandwami, V., Nagar, R. and Agrawal, V. (2016) Crushed Rock Sand-An Economical and Ecological Alternative to Natural Sand to Optimize Concrete Mix. Perspectives in Science, 8, 345-347. 


\section{Appendix}

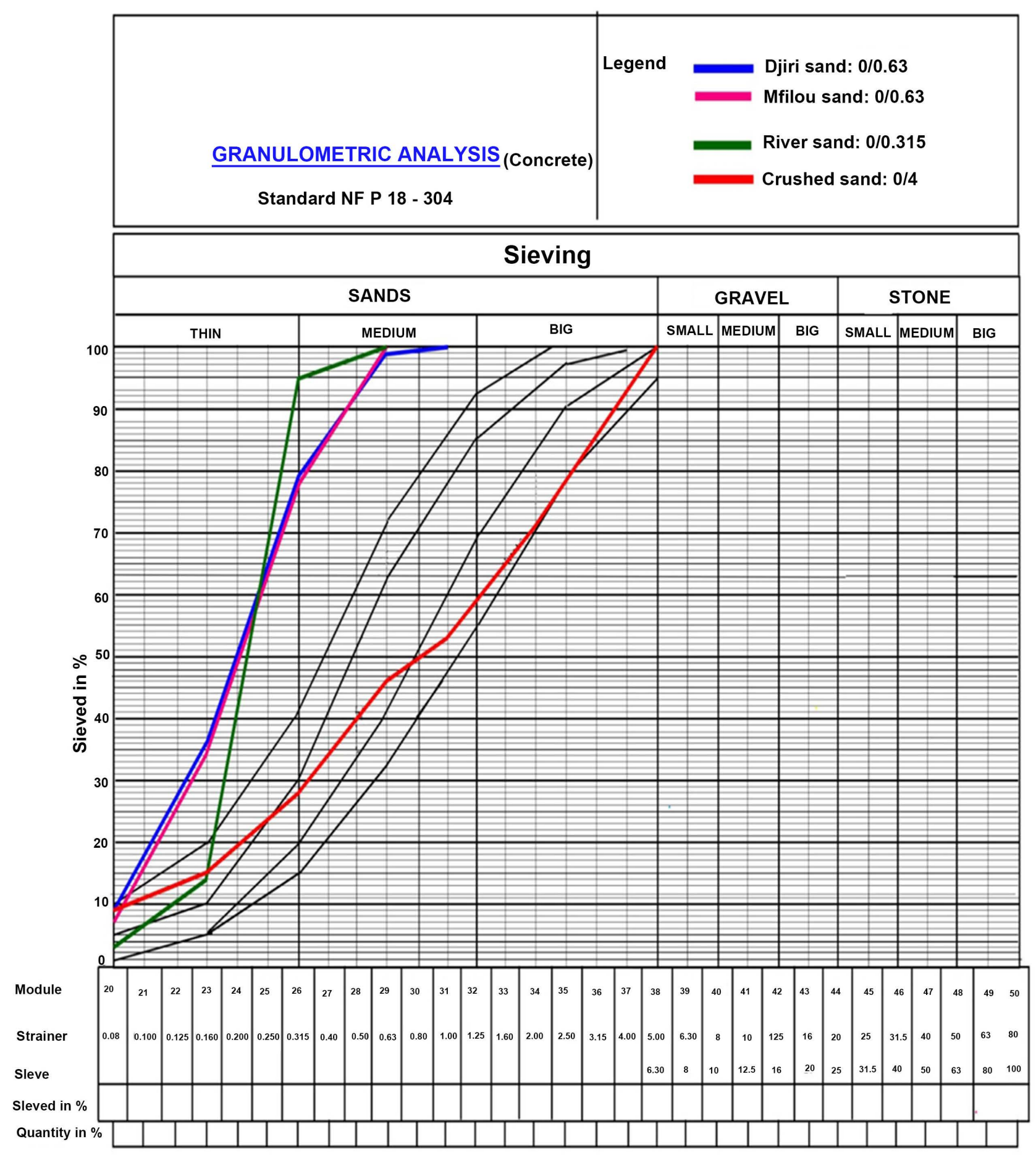

Annex 1. AG curve of natural sands. 


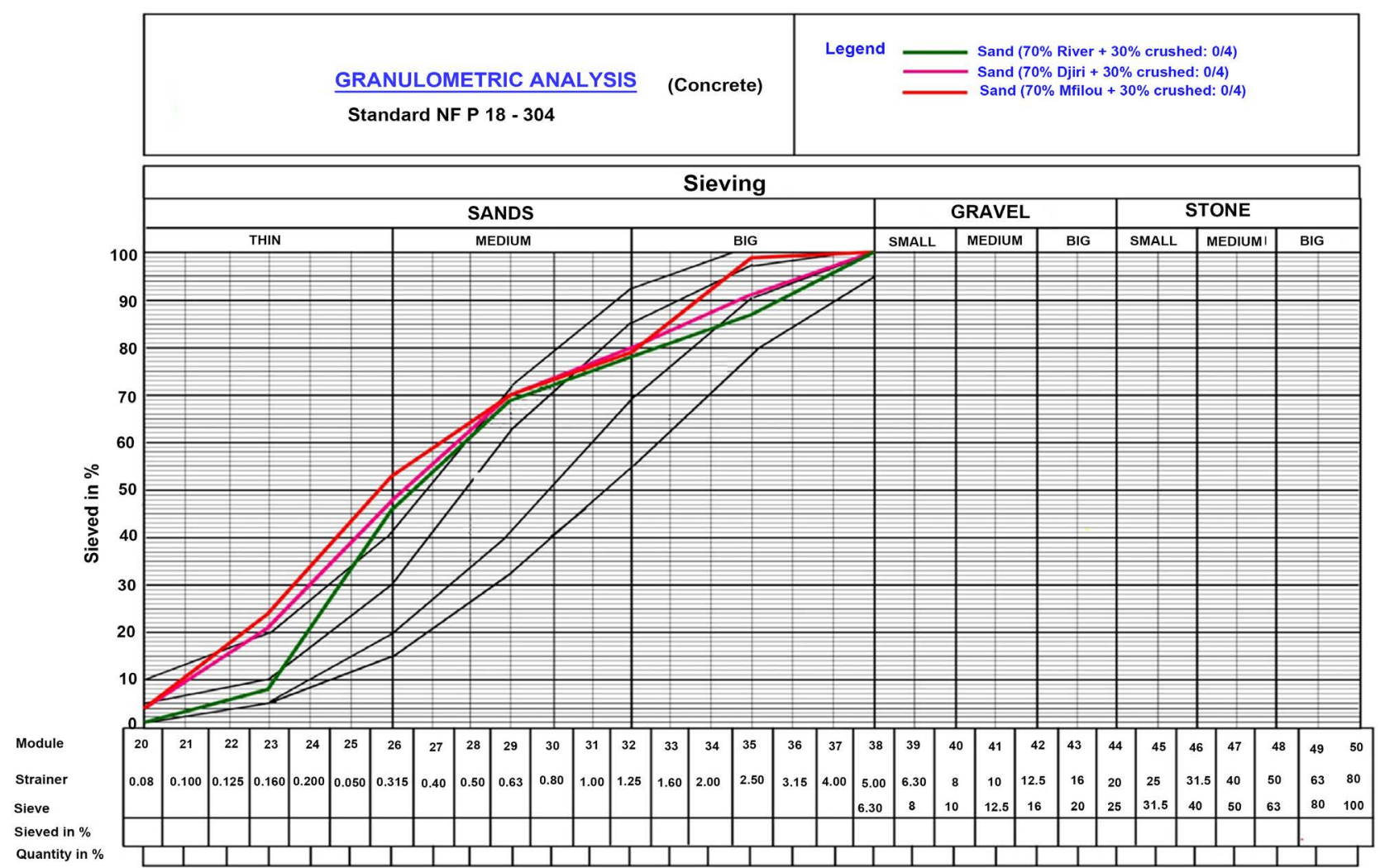

Annex 2. Improved sand AG curve.

Annex 3. Calculation note granulometric analysis of Mfilou sand.

\begin{tabular}{|c|c|c|c|c|c|c|}
\hline \multicolumn{7}{|c|}{$\begin{array}{c}\text { Origin: Brazzaville } \\
\text { Sample: White Mamboo Quarry Sand (Mfilou) }\end{array}$} \\
\hline \multicolumn{7}{|c|}{ Initial dry weight: 300 grs } \\
\hline $\begin{array}{l}\text { Module } \\
\text { AFNOR }\end{array}$ & $\begin{array}{l}\text { Sieve } \\
(\mathrm{mm})\end{array}$ & $\begin{array}{l}\text { Strainer } \\
\phi(\mathrm{mm})\end{array}$ & $\begin{array}{l}\text { Cumulative } \\
\text { refusal }\end{array}$ & $\%$ refusal & $\%$ Passant & Observation \\
\hline 29 & 0.63 & 0.8 & 0 & 0 & 100 & 100 \\
\hline 26 & 0.315 & 0.40 & 67.2 & 22.4 & 77.60 & 78 \\
\hline 23 & 0.100 & 0.200 & 193.6 & 64.53 & 35.47 & 35 \\
\hline 20 & 0.08 & 0.1 & 278.3 & 92.77 & 7.23 & 7 \\
\hline
\end{tabular}

The module of fineness of this sand is $\mathrm{Mf}=0.87$.

Annex 4. Calculation note for the bulk density test of Djiri sand.

\begin{tabular}{cccccc}
\hline \multicolumn{7}{c}{ Sample: Djiri white quarry sand } \\
\hline Number of tests & 1 & 2 & $\mathbf{3}$ & $\mathbf{4}$ & $\mathbf{5}$ \\
\hline Total dry weight & 1834.9 & 1837.7 & 1836.9 & 1840.5 & 1836.2 \\
Mould weight & 277.4 & 277.4 & 277.4 & 277.4 & 277.4 \\
Net weight of material & 1557.5 & 1560.7 & 1559.5 & 1563.1 & 1558.8 \\
Mould volume & 1000 & 1000 & 1000 & 1000 & 1000 \\
Density & 1.56 & 1.56 & 1.56 & 1.56 & 1.56 \\
& & & & 1.56 &
\end{tabular}


Annex 5. Calculation note of the specific weight of Mfilou sand.

\begin{tabular}{ccc}
\hline \multicolumn{2}{c}{ Sample: Mfilou white quarry sand } & \\
\hline Pycnometer No. & 1 & 4 \\
\hline Weight Empty Pycnometer P0 & 421.3 & 413.6 \\
Weight Pycnometer + Dry materials P2 & 860.3 & 722.0 \\
Weight Pycnometer + Materials + Water P3 & 1230.8 & 1148.9 \\
Weight Pycnometer + Water P1 & 965.0 & 962.0 \\
Volume Pycnometer P1 - P0 = P4 & 543.7 & 548.4 \\
Volume Materials P2 - P0 = P5 & 439.0 & 308.4 \\
Remaining Water Volume P3 - P2 = P6 & 370.5 & 426.8 \\
Volume Materials P4 - P6 = P7 & 173.2 & 121.6 \\
Specific Gravity P5/P7 & 2.53 & 2.54 \\
Average & & 2.54 \\
\hline
\end{tabular}

